\title{
Development and clinical application of Korean-version nonword intervention to improve speech motor programming*
}

\author{
Da-Hee $\mathrm{Oh}^{1,2} \cdot \mathrm{Ji}-\mathrm{Wan} \mathrm{Ha}^{3, * *}$ \\ ${ }^{\prime}$ Department of Speech and Language Pathology, Graduate School of Rehabilitation, Daegu University, Gyeongsan, Korea \\ ${ }^{2}$ Brain Convergence Research Center, Korea University College of Medicine, Seoul, Korea \\ ${ }^{3}$ Department of Speech Pathology, Daegu University, Gyeongsan, Korea
}

\begin{abstract}
This study is to develop a Korean version of nonword intervention by modifying and supplementing a Rapid syllable transition treatment (ReST) and to determine its effect by applying it to children with CAS. Ultimately, the purpose of this study is to investigate whether nonword interventions are effective for nonword production ability and generalization of real words. Single-subject research using the ABA design was performed for a child aged five years and six months with diagnostic features of CAS. The nonwords used in the interventions were made suitable for the individual child. The intervention was provided in one-hour sessions, twice a week for six weeks. In all cases, performance of the treated three-syllable nonwords improved, and untreated three-syllable words, four-syllable words, and nonwords showed a generalization effect. However, the generalization of treatment effects to words was smaller than for nonwords. The nonword intervention was effective in improving the subject's speech motor programming skills. As a result, transition errors due to impaired speech motor programming were greatly reduced, and the ability to produce untreated nonwords was greatly increased. However, there was a limit to the full improvement of strongly habitable word errors, which would be expected if a more intensive and repetitive intervention schedule was provided.
\end{abstract}

Keywords: childhood apraxia of speech, nonword intervention, speech motor programming

\section{1. 서론}

역사적으로 아동기 말실행증(childhood apraxia of speech, CAS) 은 임상가들에게 큰 고민을 안겨주었다. 아동기 말실행증의 중 재 효과를 입증한 연구가 거의 없을 뿐만 아니라 여타 말소리장
애와 상당히 중첩되는 특성을 가지고 있어, 아동기 말실행증을 선별하는 것조차 쉽지 않기 때문이다. 이러한 이유로 일부 학자 들은 아동기 말실행증이 독립된 진단명으로 분류할 수 있는 장 애인지 그 실체 자체에 의구심을 품기도 하였다. 논쟁의 답을 찾 기 위해 American Speech- Language-Hearing Association(ASHA)

\footnotetext{
* This research was supported by Basic Science Research Program through the National Research Foundation of Korea (NRF) funded by the Ministry of Education (NRF-2020R1I1A3074130).

**jw-ha@daegu.ac.kr, Corresponding author

Received 2 June 2021; Revised 10 June 2021; Accepted 10 June 2021

(c) Copyright 2021 Korean Society of Speech Sciences. This is an Open-Access article distributed under the terms of the Creative Commons Attribution NonCommercial License (http://creativecommons.org/licenses/by-nc/4.0) which permits unrestricted non-commercial use, distribution, and reproduction in any medium, provided the original work is properly cited.
} 
은 2002년에 CAS 임시위원회를 구성하였고, 5 년간의 방대한 문 헌연구를 통해 그 결과를 발표하였다. ASHA의 기술보고서에 의하면 아동기 말실행증은 첫째, 음절이나 단어를 반복할 때 자 음과 모음에서 비일관적 오류를 보이고, 둘째, 음소와 음절의 동시조음 전환(coarticulatory transition)이 연장되거나 방해를 받 으며(disrupted), 셋째, 어휘 또는 구의 강세패턴 산출 시 부적절 한 운율을 그 특징으로 한다. ASHA의 발표 이후, 아동기 말실 행증의 핵심증상에 대해 다수 학자들 간 의견의 일치를 보이기 시작하였고(Ballard et al., 2010; Shriberg et al., 2012; Thomas et al., 2017), 이후 핵심증상을 유발하는 기저의 결함에 대해서도 어느 정도 합의점을 찾았다.

말은 다양한 움직임의 파라메타(parameters)로부터 생성되며, 이것은 말 움직임의 속도, 강도, 순서(sequence) 등의 변화를 의 미한다. 이러한 파라메타는 빠르기, 크기, 강약 조절의 변수가 될 뿐 아니라 동시조음의 결합에 영향을 미치는 요인으로 작용 한다(McCabe et al., 2017). 특정 말산출에 관여하는 파라메타들 은 근육으로 보내는 명령들의 집합체인 특정운동계획(specific motor plan, SMP)을 구성하는데, 여기에는 개별 음소에 대한 공 간적 지시뿐 아니라 타이밍에 대한 시간적 지시도 포함된다. 아 동기 말실행증의 근본적 결함은 이러한 시간적, 공간적 파라메타 의 손상에서 비롯된다(American Speech-Language-Hearing Association, 2007; Park, 2015). 이를 반영하여 ASHA(2007)는 아동기 말실행증에 대해 '신경 근육에 문제가 없음에도 불구하고 연속 적인 말운동에 관한 중요한 계획 및/또는 시공간 프로그래밍의 손상으로 인해 말소리 산출과 운율에 오류가 발생하는 신경학 적 아동(소아) 말소리장애’라고 정의하였다. 다시 말해 말실행 증 아동은 조음기관의 구조 및 기능적 손상은 없으나, 그것을 언제, 어떻게 움직여야 하는지, 즉 운동지시(motor instruction) 에 어려움이 있으며, 좀 더 구체적으로는 운동지시에 포함된 말 운동계획 및 프로그램을 만들고 수정하고 인출하는 데에 결함 이 있다.

최근에는 이와 같은 이론적 배경을 바탕으로 아동기 말실행 증의 중재법을 고안한 연구들을 찾아볼 수 있는데, 그 중 하나 가 ReST(rapid syllable transition treatment)이다(McCabe et al., 2017). ReST는 전통적인 언어치료와는 사뭇 다른 특징을 갖는 다. ReST의 목표는 목표단어 산출 시 정확한 소리(sounds)와 운 율(prosody) 그리고 민첩한 전환(transition)을 동시에 성공시키 는 것이다. 즉, 아동기 말실행증의 세 가지 핵심증상을 중재의 목표로 하는데, 이 때 중재 자극어로 비단어를 사용하는 것이 ReST의 특징이다. '비단어(nonword) 혹은 무의미단어(nonsense word)'는 다양한 분야에서 흥미로운 주제로 연구되어 왔다. 특 히 음운작업기억, 음운처리, 말운동프로그래밍 능력 등을 평가 하기 위해 비단어 따라말하기를 사용한 연구가 활발하게 진행 되어 왔다(Kim et al., 2015; Song, 2008). 그러나 비단어를 중재 에 활용한 연구는 찾아보기 어렵다.

비단어는 말운동과 관련하여 말실행증 아동이 가지고 있는 기저의 근본적 결함을 개선시킬 수 있는 최적의 도구일 수 있다 (McCabe et al., 2017). 처음 접하는 단어를 듣고 따라 말할 때, 화
자는 머릿속에서 즉각적으로 새로운 운동프로그램을 창조해야 하며, 이것을 말운동프로그래밍(motor-speech programming)이 라 한다. 비단어를 처음 접하는 낯선 단어라고 가정할 때, 이 낯 선 단어를 따라말하기 위해 필수적으로 요구되는 능력이 바로 프로그래밍 기술이다. 다시 말해, 자주 사용하는 단어는 충분히 학습된 근육운동명령의 조합에 의해 자동으로 수행되는 반면, 낯선 비단어는 수행에 필요한 산출정보들이 전무하기 때문에 새로운 운동프로그램을 만들어야 한다. 즉, 비단어 산출은 하향 식 처리과정(top-down approach)의 영향을 통제하고 전적으로 상향식 처리과정(bottom-up approach)에 의존한 실시간적 운동 프로그래밍이 요구되는 활동이다. 이와 관련하여 많은 선행연 구들이 비단어와 단어의 산출 특성을 비교함으로써, 비단어 산 출이 화자의 운동프로그래밍 능력을 반영한다는 것을 이미 확 인한 바 있다(Song, 2008; Stackhouse \& Wells, 1993; Vance et al., 2005). 이러한 이론에 근거할 때, 중재에 비단어를 이용하는 것 은 운동프로그래밍 단계를 활성화시키는 데에 다분히 긍정적 인 영향을 줄 수 있다는 추론이 가능하다. 말실행증은 추상적 음운코드를 말운동명령으로 변환시키는 단계 즉, 프로그래밍 단계에 손상이 있는 장애이기 때문에(Ballard et al., 2010), 비단 어의 반복 산출훈련은 말실행증 아동이 가진 근본적 결함에 가 장 가깝게 접근하여 이를 직접적으로 다루어주는 방법으로 여 겨진다. 따라서 ReST는 말실행증 아동의 기저의 결함인 말운동 프로그래밍 능력 자체를 향상시킴으로써, 말실행증의 핵심증 상인 비일관적 오류, 민첩하지 못한 전환, 부적절한 운율을 개 선시키는 치료법이라 할 수 있다. 다만 유의할 점은, ReST가 중 재도구로서 비단어의 중요성을 강조하고는 있지만, 비단어는 단어를 산출하기 위한 템플릿(template)일 뿐 중재의 궁극적 목 적은 단어로의 일반화라는 것을 간과해서는 안 된다.

더불어 ReST의 또 다른 차별점은 중재원리에 있다. ReST는 운동학습원리(principles of motor learning, PML)를 기반으로 설 계되었다. 운동학습은 움직임에 있어 영구적 변화를 가져오는 일련의 처리과정을 말한다(Schmidt \& Lee, 1999). 특정 동작을 지속적으로 연습하고 학습할 때 운동학습 전과 후의 신경계 처 리과정은 근본적으로 달라지며, 그 변화로 인한 효과는 장기적 으로 지속된다(Kwon, 2008). 이를 위해 운동학습의 원리는 두 가지 구성요소인 훈련단계(training phase)와 연습단계(practice phase)를 포함한다. 따라서 본 연구에서도 이를 반영하여 중재 절차를 훈련과 연습의 두 단계로 구분하였다. 훈련단계는 성공 적인 비단어 산출을 위한 움직임의 방법과 기술을 습득하는 도 입부 역할을 한다. 이 단계에서 아동은 비단어를 산출하기 위한 운동정보가 전혀 없기 때문에 비일관적이고 많은 수의 오류를 보인다. 이때 임상가는 아동의 반응에 대해 즉각적이고 구체적 인 피드백(knowledge of performance, $\mathrm{KP}$ or KP feedback)을 제공 하고, 다양한 기술을 통해 아동이 올바른 산출을 경험할 수 있 게 해야 한다. 특히 중재의 1 2회기는 훈련단계에 집중적으로 시간을 할애하여 새로운 운동 패턴을 학습할 수 있는 충분한 시 간을 제공하는 것이 원칙이다. 훈련단계에서는 다섯 개의 비단 어를 모두 정확히 산출하였는지 여부가 새로운 운동패턴의 습 
득 기준으로 제시된다.

이후 단계에서는 학습한 패턴의 효율성을 증가시키는 촉진 단계를 거치는데, 이 단계를 연습단계라고 한다. 이 때 장기적 운동학습에 지대한 영향을 미치는 변수는 연습의 양(amount of practice)과 피드백(feedback)의 빈도이며, 이것을 반영한 단계가 바로 연습단계이다. 연습단계에서는 회기 당 20 개의 비단어를 최소 5 세트 이상 반복해야 한다. '세트'란 비단어 산출 연습활동 과 휴식시간(resting interval)을 합쳐서 부르는 말이다. 한 회기의 시간은 60 분이며, 만일 지정된 연습량을 다 채웠음에도 60 분이 지나지 않았다면 회기가 종료될 때까지 가능한 많이 산출활동 을 반복한다. 기준에 도달한 후에도 지속적인 연습과 훈련을 반 복하는 것은 어떤 측면에서는 비경제적일 수 있지만, 과연습 (overpractice)은 운동프로그램에 저장된 기억을 더욱 강화시키 고, 학습된 운동기술을 장기적으로 유지할 수 있게 해준다 (Schmidt \& Lee, 1999). 따라서 연습단계에서는 연습의 최대량 을 제한하지 않는다.

운동학습에 영향을 주는 또 다른 변수인 피드백 빈도와 관련 하여, Winstein \& Schmidt(1990)는 피드백을 $100 \%$ 제공한 집단 과 $50 \%$ 제공한 집단 간 운동학습의 변화를 비교하였다. 그 결과 중재기간 동안에는 두 집단 간 움직임의 정확도에 차이가 나타 나지 않았으나, 중재 종료 24시간 후에는 피드백을 $50 \%$ 만 제공 한 집단의 움직임의 정확도와 반응시간이 유의하게 좋았다. 이 에 Swinnen et al.(1990)은 피드백 양을 50\%로 통제한 채 피드백 제공 일정에 변화를 주어 추가실험을 실시하였다. 그 결과 일정 하게 혹은 점차 빈번하게 피드백을 제공한 집단보다 점차 간헐 적으로 피드백을 제공한 집단이 중재 종료 24시간 후 유의하게 향상된 운동능력을 보임을 확인하였다(Kwon, 2008). 따라서 본 연구에서는 이러한 연구결과를 반영하여, 각 훈련세트 별로 피 드백의 양과 일정에 제한을 둠으로써 피드백의 빈도를 조절하 였다. 예를 들어 20 개의 비단어를 1 세트로 총 5 세트를 반복한다 고 가정하였을 때, 첫 번째 세트에서는 20 회의 시도 중 18 회의 시도에 피드백이 제공된다. 이후 빈도를 점차 줄여 마지막 세트 인 5 번째 세트에서는 20 회의 시도 중 2 회의 시도에만 피드백이 제공된다. 결과적으로 100 회의 시도 중 50 회의 시도, 즉 평균적 으로 반응의 $50 \%$ 에만 피드백이 제공되는 셈이다. 이 때 유의할 점은 연습단계에서 제공하는 피드백은 '결과에 대한 지식 (knowledge of result, KR)'이기 때문에, 아동의 반응에 대해 정/ 오반응 판단만을 제공해야 한다는 것이다. 이와 달리 훈련단계 에서는 피드백의 빈도에 제한이 없으며, 반응의 결과뿐 아니라 왜 틀린 반응을 보였는지, 어떻게 하면 올바른 반응을 할 수 있 는지 등에 대해서도 최대한 구체적인 정보를 제공해야 한다.

이와 같은 운동학습원리를 기반으로 한 비단어 중재인 ReST 를 활용하여 긍정적 효과를 입증해낸 중재 연구는 최근 국외에 서 활발하게 발표되었다(Ballard et al., 2010; Murray et al., 2012; Murray et al., 2015; Thomas et al., 2017). 그러나 국내의 경우 $\mathrm{ReST}$ 를 소개하거나 사용한 문헌을 찾아보기 어렵다. 또한 한국 어는 영어와 언어적 특성이 다소 다르기 때문에 영어권 ReST 방법을 국내 말실행증 아동에게 그대로 적용하는 것에는 무리
가 있다. 이에 본 연구에서는 한국어 실정과 맞지 않는 ReST 요 소들을 수정 및 보완하여 한국어 버전의 비단어 중재로 재설계 하고자 하였으며, 이를 국내 말실행증 아동에게 적용하여 비단 어 중재가 아동기 말실행증에 미치는 효과에 대해 알아보고자 하였다. 뿐만 아니라 비단어가 단어 산출을 위한 템플릿의 역할 을 하는 만큼, 비단어를 사용한 중재가 실제 단어의 산출 또한 개선시킬 수 있는지, 즉, 단어로의 일반화 효과가 있는지 확인 하고자 하였다. 이를 위해 본 연구에서는 첫째, 한국어 비단어 중재접근법의 가인드라인을 확립하고, 둘째 가인드라인에 따 라 중재를 실시한 후 그 효과를 입증하고자 하였다. 이와 같은 연구 목적을 위해 전체 연구를 연구 1 과 연구 2 로 구분하여, ‘한 국어 비단어 중재접근법의 확립'과 '한국어 비단어 중재접근법 의 임상 적용’을 각각 진행하였다.

\section{2. 연구 1: 한국어 비단어 중재접근법 확립}

\section{1. 연구 방법}

비단어 중재를 위한 자극어 선정, 중재 절차, 채점 방법에 대 한 가이드라인을 확립하기 위해, 다음과 같은 절차로 연구를 진 행하였다.

\subsection{1. 문헌 연구}

$\mathrm{ReST}$ 와 비단어 따라말하기에 관한 선행연구들(Ballard et al., 2010; McCabe et al., 2017; Murray et al., 2012; Murray et al., 2014; Murray et al., 2015; Ryu \& Ha, 2018; Shriberg et al., 2012; Thomas et al., 2017)을 참고하여 1차 가이드라인을 제작하였다. 연구자 간 합의를 통해 선행연구와 차별적으로 수정 또는 추가된 부분 은 다음과 같다. 첫째, ReST에서는 자극어 제작 시 세 개의 장모 음과 하나의 약모음(weak vowel) 또는 중성모음(neutral vowel) 을 포함해야 하는 규정이 있으나, 모음의 장단과 강약 구분은 한국어의 실정에 적절하지 않다고 판단하여 이 규정은 제외하 였다. 둘째, 일반화 효과 확인을 위해 비단어뿐 아니라 단어 선 정 기준 또한 마련하였다. 셋째, 아동의 변화를 심층적으로 파 악하기 위해, ReST에서 제안한 반응정확도 이외에 $\mathrm{Kim} \&$ $\mathrm{Ha}(2014)$ 및 $\mathrm{Ryu} \& \mathrm{Ha}(2018)$ 의 연구를 참고하여 인출 점수와 배 열 점수를, Shriberg et al.(2012)의 연구를 참고하여 첨가오류 발 생률을 채점 체계에 포함하였다. 첨가오류의 경우 말실행증 아 동의 음소전환 결함과 관련하여 해석할 수 있기 때문에(Shriberg et al., 2012), 첨가오류를 수치화하여 치료 전후의 차이를 비교 하는 것 또한 말운동프로그래밍 능력의 변화에 대해 시사하는 바가 있을 것이다. 넷째, 왜곡오류의 처리 방법에 있어 선행연 구(Ryu \& Ha, 2018)와 차이를 보인다. 선행연구에서는 왜곡을 정반응으로 간주하였으나, 본 연구에서는 왜곡을 오반응으로 처리하였다. 음운처리능력에 초점을 둔 선행연구와 달리, 본 연 구의 비단어 중재법은 말운동능력 향상을 위한 것이므로 운동 능력의 결함을 시사하는 왜곡오류를 정반응으로 처리하는 것 은 무리가 있다고 판단하였다. 


\subsection{2. 전문가 자문}

1 차 가이드라인에 대한 전문가 자문을 실시하였다. 석사 학 위를 소지하고 있거나 석박사 학위 과정 중에 있는 1급 또는 2 급 언어재활사 13 명이 자문에 참여하였다. 이들은 모두 다수의 말소리장애 아동을 평가하고 치료한 경험이 있었다. 연구자 1 인이 1 차 확정된 비단어 중재접근법의 전 과정을 PPT 발표형식 으로 설명하였고, 이후 보완이나 수정이 필요한 사항에 대해 모 든 참여자들이 자유롭게 의견을 제시하였다. 이들의 의견을 반 영하여 가이드라인 2차안이 완성되었다.

\subsection{3. 예비 실험}

말실행증 아동 1 명을 대상으로 2차 가이드라인 절차대로 두 차례의 예비실험을 실시하였다. 예비실험의 목적은 중재의 효 과를 입증하기 위한 것이 아니라 중재 절차 상 문제가 없는지를 확인하기 위한 것이었다. 예비실험 과정에서 관찰된 문제점을 보완하여 최종 가이드라인을 확정하였다.

\section{2. 연구 결과}

자극어 선정, 중재 절차, 채점 방법에 대한 최종 가이드라인 은 다음과 같다.

\subsection{1. 자극어 선정 원칙 확립}

중재에 사용될 비단어를 만드는 조건은 다음과 같다. 첫째, 아동의 음성목록에서 자음과 모음을 네 개씩 선정한다. 둘째, 자음의 경우 아동이 어두초성 위치에서 정확하게 산출할 수 있 는 소리여야 하는데, 선택된 자음들은 최대한 서로 달라야 한 다. 이 때 '최대한 서로 다르다'는 것은, 예를 들어 4 개의 자음 중 2 개의 자음이 서로 다른 위치와 다른 방법으로 산출되고, 1 개의 자음은 반드시 [+공명성]의 자질을 가질 것을 의미한다. 셋째, 모음의 경우 아동의 음성목록에 있는 소리여야 하므로 혀 의 높이 및 앞뒤 위치, 입술 모양에 상관없이 아동이 $80 \%$ 이상 정조음하는 소리들로 구성한다. 이때 이중모음은 제외한다. 넷 째, 대상 아동이 적어도 5 개의 3 음절 단어를 산출할 수 있다면 $\mathrm{CVCVCV}$ 구조의 3음절 비단어로, 그렇지 않다면 $\mathrm{CVCV}$ 구조의 2음절 비단어로 중재를 시작한다.

일반화 효과를 확인하기 위한 단어 선정 기준은 첫째, 목표 비단어와 동일하거나 유사한 자음들로 구성할 것, 둘째, 종성을 포함하지 않는 구조일 것의 두 가지이다. 종성이 없는 3음절 또 는 4음절 단어는 다소 제한적이기 때문에, 1음절 또는 2음절 단 어를 조합한 합성단어를 일부 허용할 수 있다. 예를 들어 '토끼' 와 ‘모자’를 조합하여 ‘토끼모자’를 목표어에 포함할 수 있다.

이상과 같은 절차를 거쳐 제작된 중재용 비단어 20 개와 일반 화용 단어 및 비단어 각 20 개가 자극어 한 세트를 구성한다.

\subsection{2. 중재 절차 확립}

비단어 중재는 훈련단계(training stage)와 연습단계(practice stage)로 구성된다. 훈련단계는 비단어를 성공적으로 산출하는 방법을 가르쳐 조음기의 정확한 움직임을 경험하게 하는 것이
목적이다. 훈련단계의 성취 준거는 5 개의 비단어를 정확하게 따라말하는 것으로, 여기서 말하는 ‘정확하게'의 기준은 소리와 운율을 정확하게 따라하고 음절 간 전환이 적절한 타이밍으로 이행되는 것을 말한다. 목표로 하는 5 개의 비단어는 20 개의 목 표 비단어 중 무작위로 선택하고, 2회기 이후부터는 이전 회기 에서 지속적으로 오류를 보인 5 개의 비단어를 목표로 선정한다. 이때 목표 성취를 위해 제공되는 단서의 제한은 없다. 즉, 조음 점 지시법, 모음 연장, 시각 및 촉각 단서 등 모든 전략을 동원하 여 정반응을 유도할 수 있으며, 이 단계에서 보인 반응에 대해 서는 정/오반응을 측정하지 않는다. 훈련단계에서 가장 중요한 것은 비단어를 성공적으로 산출하는 전략을 찾아내는 것이다. 이는 아동 별로 다양할 것이며, 따라서 치료사는 각 아동 별로 가장 최적화된 전략을 찾아내야 한다. 훈련단계의 소요시간은, $1 \sim 2$ 회기에는 약 20 30분, 3 회기부터는 10 분 이내로 제한하여 이후 대부분의 시간을 연습단계에 할애하도록 한다.

훈련단계에서 비단어를 성공적으로 산출하기 위한 전략을 찾았다면, 연습단계에서는 그 운동패턴을 안정적으로 보유하 기 위해 해당 운동을 반복한다. 연습단계의 목적은 움직임의 일 관성을 확립하여 운동체계에 장기적 변화를 촉진하는 것이다. 때문에 성공적 운동 산출 전략을 모색하는 1 2회기를 제외하 고, 3 회기 이후부터는 대부분의 중재 시간이 연습단계로 이루 어진다. 연습단계에서 각 연습 세트는 20 개의 비단어를 1 회씩 따라말한 후, 2 분의 휴식시간을 갖는 것으로 구성된다. 휴식시 간은 집중적 반복훈련에 대한 보상으로, 말, 언어 또는 문해로 이루어진 활동은 삼가고 오로지 아동이 흥미를 느끼는 놀이활 동으로만 구성한다. 만일 2회의 연습 세트 동안 40 회의 시도 중 4 회 이하, 즉 $10 \%$ 이하의 정반응률을 보일 경우, 다시 훈련단계 로 돌아가야 한다. 반면 $10 \%$ 이상의 정반응률을 보인다면 계속 해서 연습단계를 진행하여 최소 5 회 이상의 연습 세트를 반복 한다.

이 때 가장 주의를 기울여야 하는 것은 피드백의 방법과 빈도 이다. 훈련단계와 달리 연습단계에서 중재자는 오류를 정반응 으로 유도하지 않고, 아동의 반응에 대해 정/오 판단만 제시한 다. 이러한 '결과에 대한 지식(knowledge of result, KR)'은 비단 어 중재의 핵심 요소로, 아동으로 하여금 본인의 발화를 자기주 도적(self-directed)으로 변화시키고 이에 대해 자가점검(selfmonitoring)의 기회를 제공하는 장치이다. 피드백을 제공하는 빈도 또한 엄격하게 규정되어 있다. 5세트를 반복할 경우 20회 의 시도 중 첫 번째 세트에서는 18회, 두 번째 세트에서는 14회, 세 번째 세트에서는 10 회, 네 번째 세트에서는 6 회, 다섯 번째 세트에서는 2 회의 피드백만을 제공하여, 결과적으로 총 100 회 의 시도 중 평균 $50 \%$ 에 대해서만 피드백을 제공하도록 하였다. 연습단계의 성취 준거는 연속적인 두 번의 회기에서 $80 \%$ 이상 정반응하는 것이다. 연습단계에서 보인 아동의 반응은 모두 측 정, 기록되어야 한다. 전체 회기의 중재 절차를 도식화한 흐름 도는 부록 1 에 제시하였다.

\subsection{3. 채점 체계 확립}


2.2.3.1. 반응정확도

반응정확도(response accuracy)는 정반응 점수를 백분율로 나 타낸 값이다. 정반응 점수는 아동이 1 개의 비단어를 정확하게 산출할 때마다 1 점씩 부여한다. 이때 정확도의 기준은 단순히 조음의 정확도가 아니며, 조음, 전환, 운율의 정확도를 말한다. 단, 이 세 가지 요소가 ‘동시에’ 정확하게 실현되어야만 정반응 으로 인정한다. 각 요소의 판단 기준은 다음과 같다. 첫째, 조음 정확도는 각 음소가 정확한 위치, 방법 및 발성유형으로 산출되 었는지를 판단하는 것이다. 이때 왜곡도 오반응에 포함한다. 둘 째, 전환정확도는 각 음소가 정확한 타이밍(timing)에 전환되었 는지 판단하는 것으로, 음소 간 전환이 유창하게 이루어졌을 때 정반응 처리한다. 타이밍 오류의 예로 어중초성을 앞 음절 어중 종성부터 연결하여 발음하거나(예: /타찌무/-[타찜무]), 각 음절 을 끊어서 말하는 스타카토(staccato) 발화를 들 수 있다. 셋째, 운율정확도는 3음절 비단어의 음 높낮이(pitch)가 정확한 경우 를 말하는데, 아동이 산출한 비단어의 오르-내림 형태가 치료사 가 제공한 것과 청지각적으로 일치했을 때 정반응으로 처리한 다. 이와 같은 세 가지 요소가 모두 정확하게 산출되었을 때 1 점 을 부여한다.

정오반응 판단 시 유의할 점은 아동에게 주어진 발화기회는 단 한 번뿐이라는 것이다. 본 비단어 중재는 오류를 허용하지 않기 때문에, 아동 스스로 본인의 오류를 곧바로 수정한 경우도 틀린 반응으로 간주한다. 1 세트가 20 개의 비단어로 구성된 경 우, 1 세트에서 획득할 수 있는 최대 점수는 20점이다. 비단어중 재는 5세트 이상 반복되기 때문에 모든 시도에 대한 정반응 점 수의 백분율 값을 1 회기의 반응정확도로 측정한다.

\subsubsection{2. 인출 점수}

인출 점수(retrieval score)는 정확하게 인출한 자음과 모음에 대해 각 1점씩 부여하는 것이며, 왜곡오류는 오반응에 포함되 기 때문에 점수를 얻지 못한다. 이때 해당 음소가 정확한 위치 에서 산출되었는지는 고려하지 않는 것에 주의 한다. 예를 들어 3음절 비단어/투짜메/를 [투마쩨]라고 산출하였을 경우 두 번 째 음절과 세 번째 음절의 어중 초성을 도치시켰지만 음소의 위 치와 상관없이 목표 음소/E/, /T/, /지/, / / /, /ㅁ/, / 기/가 모두 인 출되었기 때문에, 아동의 인출 점수는 최고점수인 6점이다. 또 한 첨가 혹은 대치로 인해 목표 음소가 2회 이상 인출된 경우 동 일 음소를 중복 책정하지 않도록 주의한다. 예를 들어 비단어 / 쭈게미/를 [쭈메미]라고 산출하였다면 어중초성/ㄱ/에 대한 대 치오류로 인해 음소/ㅁ/가 2회 산출되었지만, 목표 비단어가 / 미를 한 번만 포함하고 있기 때문에 해당 음소에 대해 1점만 부 여한다. 이와 같은 방식으로 점수화할 때, 3 음절 비단어 20개로 구성된 1 세트의 전체 음소는 총 120 개(6개×20)이며, 따라서 인 출 원점수 총점은 120 점이 된다, 최종 인출 점수는 전체 인출 점 수에 대한 획득 인출 점수의 백분율로 구한다.

2.2.3.3. 배열 점수 배열 점수(sequencing score)는 산출된 음소들이 목표 비단어
의 음소 배열과 동일한 순서로 위치할 경우 순차적으로 1 점씩 부여하는 것이다. 이때 두 개의 기준점인 목표 비단어의 첫 음 소(시작점)와 마지막 음소(끝점)를 모두 고려해야 한다. 즉, 하 나의 목표 음소에 대한 배열 점수는 두 개의 기준점으로부터 각 각 측정된 후, 두 점수를 합산하여 총 배열 점수가 산정되는 것 이다. 예를 들어 목표 비단어/투짜메/를 [투짬메]라고 산출한 경우, 시작점(/E/)으로부터의 배열 점수는 어중종성 /ㅁ/ 첨가 이후의 음소들이 목표 위치와 어긋나게 되면서 /E/, /T/, /지/, / F/, /ㅁ/에만 점수가 부여되어 5점이 된다. 끝점(/-1)/)으로부터 의 배열 점수는 어중종성 /ㅁ/가 첨가되기 이전까지인/기/, /ㅁ/ 에만 점수가 부여되어 2점이 된다. 따라서 시작점 기준 점수 5 점과 끝점 기준 점수 2 점을 더해 해당 비단어에 대한 총 배열 점 수는 7점이 되는 것이다. 이와 같은 방식으로 점수화할 때 여섯 개의 음소를 가진 3음절 비단어에서 획득할 수 있는 배열 점수 는 최대 12 점(시작점 기준 6점+끝점 기준 6점)이며, 20 개 비단 어로 구성된 1 세트의 전체 배열 점수는 총 240 점이 된다. 최종 배열 점수는 인출 점수와 마찬가지로, 전체 배열 점수에 대한 획득 배열 점수의 백분율로 산출한다.

\subsubsection{4. 첨가오류 발생률}

첨가오류 발생률은 아동의 전체 반응에 대한 첨가오류의 비 율을 백분율로 계산한다.

\section{3. 연구 2: 한국어 비단어 중재접근법의 임상 적용}

말실행증 아동을 대상으로 비단어 중재접근법에 대한 단일 대상연구를 실시하였다. 모든 중재 절차는 대구대학교 생명윤 리위원회의 승인(1040621-201907-HR-061-02) 하에, 연구 1에서 확정된 최종 가이드라인에 따라 진행되었다.

\section{1. 연구 방법}

\subsection{1. 아동기 말실행증 진단}

국내에서 사용 가능한 공식적인 아동기 말실행증 진단 검사 도구가 없기 때문에, 연구자는 다음과 같은 절차로 아동기 말실 행증 선별을 위한 체크리스트를 자체적으로 제작하였다. 우선 미국언어청각협회(ASHA)의 기술보고서를 비롯한 12 개의 국내 외 선행연구(ASHA, 2007; Ballard et al., 2010; Forrest, 2003; Grigos et al., 2015; Kim et al., 2015; Lee \& Sim, 2004; Nijland et al., 2003; Park, 2008; Park, 2015; Preston et al., 2013; Shriberg et al., 2012; Thomas et al., 2017; van der Merwe \& Steyn, 2018)를 참 고하여 아동기 말실행증의 진단 특성 22 개를 빈도순으로 나열 한 뒤 상위 12 개의 항목을 선정하였다. 이후 Park(2008)의 연구 를 참고하여 해당 연구와 유사한 양식으로 말실행증 진단 체크 리스트를 구성하였다(표 1). 이와 같은 체크리스트에 근거하여 본 연구에서 사용한 아동기 말실행증 진단 기준은 첫째, Table1 에 제시된 항목 (1) (4)중 2개 이상을 포함하면서 전체 8개 이상 의 항목에 해당할 것, 둘째, 우리말 조음·음운평가(U-TAP; Kim 
\& Shin, 2004)에서 자음정확도가 -2SD이하에 속할 것, 셋째, 한 국판 레이븐 지능검사(K-CPM; Lim, 2004)에서 인지능력이 정상 범위에 속할 것, 넷째, 신경학적 병변으로 인한 근육의 손상이 없 을 것, 다섯째, 구강구조에 기질적인 문제가 없을 것이었다.

\subsection{2. 대상자 특성}

본 연구의 대상자는 위의 진단 기준에 부합하는 5 세 6 개월의 남자 아동이었다. 대상 아동 이 $\mathrm{OO}$ 의 기본 정보와 인지, 언어 및 말소리 능력 지표에 대한 점수는 표 2와 같다. 이OO 아동은 위 의 말실행증 진단 체크리스트(표 1) 항목 중 비일관적 산출 (inconsistent productions), 발화 길이 증가에 따른 어려움 증가 (increasing difficulty with increased length of utterance), 음소배열 의 어려움(poor sequencing of sounds), 탐색행동(groping), 빈번한 모음 오류(frequent vowel errors), 말소리 모방의 어려움(unable to imitate sounds), 수용언어에 비해 낮은 표현언어능력(expressive language worse than receptive), 빈번한 생략 오류(frequent sound omissions), 말명료도 저하(reduced intelligibility)의 특성을 보였으며, 비정상적인 운율은 관찰되지 않았다.

이 중 아동의 구어에서 가장 두드러지는 특성은 말소리산출 이 상당히 비일관적이라는 점이었는데, 예를 들어 /메뚜기/를 [메뚜이], [메뚜끼], [메구끼]로, /저나기(전화기)/를 [저야끼], [정 가끼], [전나끼]로 오조음하는 것과 같이 다양한 오류형태를 나 타내었다. 또한 아동이 빈번하게 보이는 독특한 비발달적 음운 오류패턴은/괴물/-[앰무], /코끼리/-[흥끼이]와 같은 어중종성 첨가였다. 이러한 첨가오류는 다른 말소리장애 하위집단에서 는 관찰되지 않는 말실행증 아동의 독특한 특성으로, 이는 음소 전환 결함에 기인한 것으로 보고된 바 있다(Maassen et al., 2001; Shriberg et al., 2012). 본 아동의 경우도 바로 뒤 음절 초성(예: '코끼리'의 /77/)과 동일한 조음위치의 말소리(예: /O/)를 앞의 음절 종성에 연결하여 산출하는 양상(예: [흥끼이]의 어중종성 / 이첨ㄱ)을 보였는데, 이 또한 긴 음소 전이구간, 민첩하지 못한 음소전환 능력 등을 시사하는 것으로 보인다. 이러한 비정상적 예기(anticipatory) 오류는 공식검사, 따라말하기 과제, 자발화 모 두에서 반복적으로 관찰되었다. 뿐만 아니라 앞에서 언급한 비 일관적 오류의 예들에서 어중초성의 경음화오류가 빈번하였던 것도 음소전환 결함과 관련하여 해석할 수 있다. 즉, 장애음의 경우 다음 음절의 초성과 조음위치뿐 아니라 조음방법까지 동 일한 말소리가 앞 음절 종성에 그대로 연결되면 어중종성생략 후 어중초성에서 경음화만 남게 된다(예: [메뚝기 $\rightarrow$ 메뚝끼 $\rightarrow$ 메 뚜끼]). 그 밖에 대상 아동의 독특한 행동 특성으로 조음동작의 시연과 탐색행동을 들 수 있는데, 단어 및 문장 따라말하기 과 제 시 아동은 치료사가 자극을 제시하는 동안에는 치료사의 입 을 주시하며 조음동작을 시연하였고, 본인의 차례에서는 발화 시작 전 탐색행동을 보이곤 하였다.
표 1. 아동기 말실행증 진단 기준

Table 1. The diagnostic criteria of childhood apraxia of speech

\begin{tabular}{c|c}
\hline No & Diagnostic criteria \\
\hline (1) & Inconsistent productions \\
\hline$(2)$ & Increasing difficulty with increased length of utterance \\
\hline (3) & Poor sequencing of sounds \\
\hline (4) & Inappropriate prosody \\
\hline (5) & Groping \\
\hline (6) & Frequent vowel errors \\
\hline (7) & Limited phonetic inventory \\
\hline (8) & Unable to imitate sounds \\
\hline (9) & Expressive language worse than receptive \\
\hline (10) & Frequent sound omissions \\
\hline (11) & Difficulty in voluntary speech movement \\
\hline (12) & Reduced intelligibility \\
\hline
\end{tabular}

표 2. 사례 아동 배경정보

Table 2. Background information of child with childhood apraxia of speech

\begin{tabular}{c|c}
\hline Characteristics & $5 ; 6$ \\
\hline Chronological age (year; month) & Male \\
\hline Gender & 26 \\
\hline REVT & 21 \\
\hline Receptive vocabulary score & \\
\hline Expressive vocabulary score & 59 \\
\hline PRES & 40 \\
\hline Receptive language age (mo) & 32.5 \\
\hline Expressive language age (mo) & 50.0 \\
\hline U-TAP & \\
\hline PCC (\%) & 21 \\
\hline PVC (\%) & 104 \\
\hline K-Raven & 51.8 \\
\hline Total CPM score & \\
\hline Standard score & \\
\hline Percentage of inconsistency (\%) & \\
\hline
\end{tabular}

REVT, receptive \& expressive vocabulary test(Kim et al., 2009); PRES, preschool receptive-expressive language scale(Kim et al., 2003); U-TAP, urimal test of articulation and phonology(Kim \& Shin, 2004); K-Raven, korean raven intelligence test(Lim, 2004); CPM, coloured progressive matrices; PCC, percentage consonants correct; PVC, percentage vowels correct.

\subsection{3. 자극어 선정}

아동의 수준을 고려하여 목표 비단어를 4 개의 자음과 4 개의 모음을 조합하여 3 음절로 제작하였다. 이때 4 개의 자음은 앞서 제시한 자극어 선정 원칙에 따라/ㅁ, E, 짜, ㄱ/로 선정하였다. 모음은 위치와 방법의 제약 없이 아동이 $80 \%$ 이상 정조음할 수 있는 소리들로 구성하였고, 이중모음은 제외하였다. 이에 최종 적으로 선정된 모음은/F, T, I, 게/이었다. 이와 같이 선정된 자음과 모음들은 메트릭스 조합을 거쳐 16 개의 음절로 만들어 졌고(표 3), 이 음절들을 다시 조합하여 3 음절 비단어를 제작하 였다. 16 개의 음절로 조합 가능한 3 음절 비단어는 총 456 개였는 데, 이 중 [+공명성] 자음을 포함하지 않는 비단어를 제외한 후 중재에 사용될 목표 비단어 20 개가 최종적으로 도출되었다.

일반화 평가를 위해 단어 및 비단어를 3음절과 4음절로 나누 어 각 10 개씩 추가 선정하였다. 중재하지 않은 비단어로의 일반 
화 확인을 위해 선정된 3 음절 비단어는 20 개의 목표 비단어를 제외한 436개의 비단어 중 선택하였고, 4음절 비단어는 앞서 제 시한(표 3) 16 개의 음절을 재조합하여 제작하였다. 또한 단어로 의 일반화를 확인하고자 목표 비단어에 포함된 /ㅁ, E, ㅉ․ ㄱ/ 와 유사한 자음들로 이루어져 있고, 어중 및 어말에 종성이 없 는 3음절, 4음절 단어를 선정하였다. 중재와 일반화에 사용된 단어 및 비단어 목록은 표 4에 제시하였다.

표 3. 비단어 제작을 위한 자음 및 모음 조합

Table 3. Example of a matrix to make syllables

\begin{tabular}{c|c|c|c|c}
\hline & /ㅁ/ & /ㅌ/ & /찌/ & /ᄀᄀ/ \\
\hline$/$ / / & /마/ & /타/ & /짜/ & /가/ \\
\hline$/$ /丁/ & /무/ & /투/ & /쭈/ & /구/ \\
\hline$/ / /$ & /미/ & /티/ & /찌/ & /기/ \\
\hline$/$ /l/ & /메/ & /테/ & /쩨/ & /게/ \\
\hline
\end{tabular}

\subsection{4. 단일대상연구 설계 및 절차}

본 연구는 단일사례 실험설계 중 $\mathrm{ABA}$ 설계를 사용하였다. 전 체 실험은 기초선 단계, 중재 단계, 유지 단계로 구성되었다. 모 든 실험 회기는 $\mathrm{G}$ 시에 소재한 $\mathrm{H}$ 연구소의 조용하고 밝은 공간에 서 총 21 주간 개별적으로 이루어졌고, 각 단계의 모든 평가 과 정은 스마트폰(iPhone 10)을 사용하여 녹음 및 녹화하였다.

기초선 단계는 중재 시작 전, 아동의 사전 능력 평가를 위해 실시되었다. 평가에는 목표 비단어 20개와 일반화용 단어 및 비 단어 각 20 개가 사용되었다. 기초선 측정은 주 1 회씩, 총 3 회기 에 걸쳐 실시되었다.

중재는 한 회기당 60 분씩 주 2 회로, 총 12 회기를 실시하였다. 목표 비단어 산출에 대한 수행력은 매 회기마다 측정하였으며, 중재 단계의 모든 과정은 신뢰도 및 중재 충실도 평가를 위해 60 분간 녹화하였다.

유지 단계는 중재 소거 2개월 뒤, 중재효과의 유지와 일반화 효과를 확인하기 위해 실시되었다. 이를 위해 중재에 사용된 20 개의 비단어와 사용되지 않은 비단어 및 단어 각 20 개를 평가하 였다. 유지단계는 기초선 단계와 동일한 조건으로 주 1 회씩 총 3회기에 걸쳐 실시되었다.

\subsection{5. 수행력 변화 측정}

반응정확도, 인출 점수, 배열 점수, 첨가오류 발생률을 매뉴 얼의 채점 방법에 따라 계산하였다. 더불어 표준화검사인 U-TAP을 이용하여 자음정확도와 모음정확도를 측정하였다.

\subsection{6. 검사자 간 신뢰도}

평가에 대한 검사자 간 신뢰도 측정을 위해 기초선, 중재, 유 지 단계의 각 회기에서 대상 아동의 반응 중 $25 \%$ 를 무작위로 추 출하였다. 추출된 녹화 자료에 대해 임상 경력 10 년 이상의 언 어치료 전공 박사과정생에게 연구자와 동일한 방식으로 점수 를 채점해줄 것을 요청하였다. 신뢰도는 관찰자간 동의한 반응 수와 동의하지 않은 반응 수를 더하여 동의한 반응 수에 대해 나눈 뒤, 100 을 곱하여 백분율로 산출하였다. 이렇게 측정된 검 사자 간 신뢰도는 기초선 단계 $93.3 \%$, 중재 단계 $96.3 \%$, 유지 단 계 $100 \%$ 였다.

\subsection{7. 중재충실도}

중재자의 비단어 중재가 목적에 맞게 충실히 수행되었는지 확인하기 위해, 임상 경력 10 년 이상의 1 급 언어재활사에게 다 음의 7 개 문항에 대해 3 점 척도로 평가해줄 것을 요청하였다. 첫째, 아동의 주의가 분산되지 않는 환경에서 개별적인 중재가 이루어졌는가, 둘째, 중재자는 명료한 발음으로 비단어를 제시 하였는가, 셋째, 훈련단계에서 제공되어야 하는 피드백의 방법 을 준수하였는가, 넷째, 연습단계에서 제공되어야 하는 피드백 의 방법을 준수하였는가, 다섯째, 훈련단계는 5 세트 이상 반복 되었는가, 여섯째, 3 회기 이후부터 연습단계에 40 분 이상의 시 간을 할애하였는가, 일곱째, 중재자는 중재의 내용을 명확히 이 해하고 중재를 원활하게 진행하였는가. 충실도는 측정된 척도 의 합을 전체 척도의 합으로 나눈 뒤 100 을 곱하여 백분율로 산 출하였으며, 이렇게 측정된 중재충실도는 $97.2 \%$ 였다.

\section{2. 연구 결과}

\subsection{1. 중재 효과}

아동은 기초선 단계 3 회기 동안 낮은 반응정확도 $(10 \%, 5 \%$,

표 4. 중재 및 일반화를 위한 단어 및 비단어 목록

Table 4. The list of words and nonwords for intervention and generalization.

\begin{tabular}{c|c|c|c|c|c}
\hline \multicolumn{2}{c|}{ Intervention } & \multicolumn{3}{c}{ Generalization } \\
\hline \multicolumn{2}{c|}{ Nonword } & \multicolumn{2}{c}{ Nonword } & \multicolumn{2}{c}{ Word } \\
\hline \multicolumn{2}{|c|}{ 3-syllables } & 3-syllables & 4-syllables & 3-syllables & 4-syllables \\
\hline 마게쭈 & 무타게 & 마게찌 & 마구티쩨 & 무지개 & 타조머리 \\
\hline 메짜티 & 미테짜 & 타쭈미 & 무타쩨가 & 머리띠 & 토끼모자 \\
\hline 메구타 & 투메짜 & 투미짜 & 투기머짜 & 주사기 & 개미지도 \\
\hline 타찌무 & 티무게 & 짜미테 & 짜게미투 & 거부기 & 매미기차 \\
\hline 테기마 & 테가무 & 가테무 & 구미타쩨 & 고구마 & 치타모자 \\
\hline 쭈가미 & 쩨티마 & 무티게 & 무가쩨티 & 두꺼비 & 할아버지 \\
\hline 찌메구 & 쩨마구 & 미투짜 & 타메구찌 & 두더지 & 해바라기 \\
\hline 짜무테 & 가티메 & 티메구 & 투쩨마기 & 개구리 & 코스모스 \\
\hline 구짜미 & 기메타 & 쭈게미 & 짜미게투 & 제주도 & 크레파스 \\
\hline 게투미 & 게마쭈 & 구찌마 & 가메찌투 & 코끼리 & 짜파게티 \\
\hline
\end{tabular}


표 5. 3 음절 중재 비단어에 대한 반응정확도와 인출 및 배열 점수

Table 5. Response accuracy, retrieval and sequencing scores for treated 3-syllable nonwords (\%)

\begin{tabular}{|c|c|c|c|c|c|c|c|c|c|c|c|c|c|c|c|c|c|c|}
\hline & \multicolumn{3}{|c|}{ Baseline } & \multicolumn{12}{|c|}{ Intervention } & \multicolumn{3}{|c|}{ Follow-up } \\
\hline & 1 & 2 & 3 & 4 & 5 & 6 & 7 & 8 & 9 & 10 & 11 & 12 & 13 & 14 & 15 & 16 & 17 & 18 \\
\hline RA & 10 & 5 & 10 & 25 & 31 & 28 & 40 & 45 & 52 & 60 & 67 & 63 & 72 & 69 & 81 & 65 & 80 & 75 \\
\hline $\mathrm{RS}$ & 82 & 86 & 81 & 86 & 87 & 88 & 94 & 81 & 95 & 96 & 97 & 94 & 96 & 97 & 98 & 95 & 95 & 95 \\
\hline SS & 60 & 60 & 64 & 73 & 77 & 77 & 78 & 85 & 85 & 92 & 90 & 89 & 90 & 88 & 95 & 96 & 97 & 87 \\
\hline
\end{tabular}

RA, response accuracy; RS, retrieval score; SS, sequencing score.

$10 \%)$ 를 안정적으로 보여주었다. 그러나 중재 도입 직후 반응정 확도는 급격히 향상되었고 인출 및 배열 점수 또한 점진적으로 증가하여, 중재 종료시점인 12 회기에서는 반응정확도 $81.25 \%$, 인출 점수 $98 \%$, 배열 점수 $95.3 \%$ 로 측정되었다. 중재 소거 2 개 월 뒤 실시한 유지단계의 첫 번째 회기에서는 반응정확도가 다 소 감소한 듯 보였으나, 이후 평가에서는 향상된 비단어 산출 능력이 여전히 유지되고 있음을 확인할 수 있었다. 인출 및 배 열 점수 또한 평균 $95 \%, 93 \%$ 으로 측정되어, 비교적 안정적으로 유지되고 있음을 알 수 있었다. 기초선, 중재, 유지 단계에서 관 찰된 대상 아동의 변화는 표 5 와 그림 1 에 제시하였다.

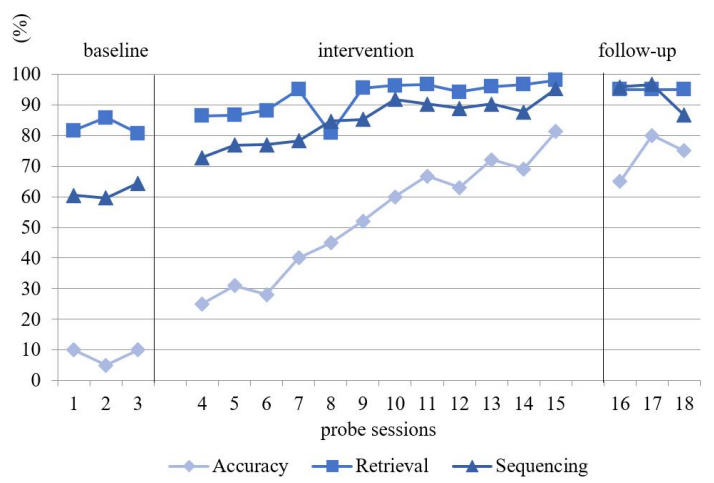

그림 1. 3 음절 중재 비단어에 대한 반응정확도와 인출 및 배열 점수 Figure 1. Response accuracy, retrieval and sequencing scores for treated 3-syllable nonwords

\subsection{2. 일반화 효과}

중재하지 않은 비단어 및 단어로의 일반화 효과를 알아보기 위해 기초선 단계에서 측정한 사전 평가와 유지 단계에서 실시 한 사후 평가를 비교하였다. 먼저 비단어에 대한 일반화 평가 결과(표 6), 3 음절 비단어는 반응정확도, 인출 점수, 배열 점수로 측정된 모든 지표가 향상되었다. 특히 배열 점수는 사전 평가에 서 $49.1 \%$ 로 인출 점수에 비해 매우 낮은 수치로 관찰되었으나, 사후 평가에서는 $90.8 \%$ 에 도달하며 눈에 띄는 향상을 나타내었 다. 4음절 비단어의 경우 반응정확도는 사전 및 사후 평가 모두 에서 $0 \%$ 로 측정되었으나, 인출 점수는 $15 \%$, 배열 점수는 $25 \%$ 가량 상승하여 4음절 비단어 또한 배열 점수에 대한 일반화 효 과가 가장 두드러짐을 알 수 있었다.

단어로의 일반화 평가 결과(표 7), 3 음절 단어의 반응정확도 는 $0 \%$ 에서 $10 \%$ 로, 4 음절 단어의 반응정확도는 $0 \%$ 에서 $30 \%$ 로 향상되어 4 음절 단어에 대한 일반화 효과가 더 큰 것으로 나타 났다. 인출 점수에서도 비슷한 경향이 관찰되었는데, 3 음절 단
어는 $6.7 \%$ 향상된 것에 반해 4 음절 단어는 $10 \%$ 의 상승률을 나 타내었다. 배열 점수의 경우 3 음절 단어의 사후 평가 결과 $72.5 \%$, 4음절 단어의 사후 평가 결과 $58.8 \%$ 로, 각각 $17.5 \%$, $16.3 \%$ 의 상승률을 보인 것을 확인하였다.

표 6. 3음절, 4음절 비단어에 대한 일반화 효과

Table 6. Generalization effect to untreated 3-, 4-syllable nonwords (\%)

\begin{tabular}{c|c|c|c|c|c|c}
\hline \multirow{2}{*}{} & \multicolumn{3}{|c|}{ 3-syllables } & \multicolumn{3}{c}{ 4-syllables } \\
\cline { 2 - 7 } & RA & RS & SS & RA & RS & SS \\
\hline Pre & 10.0 & 85.0 & 49.1 & 0 & 61.3 & 28.8 \\
\hline Post & 60.0 & 95.0 & 90.8 & 0 & 76.3 & 53.8 \\
\hline
\end{tabular}

RA, response accuracy; RS, retrieval score; SS, sequencing score.

표 7.3음절, 4음절 단어에 대한 일반화 효과

Table 7. Generalization effect to untreated 3-, 4-syllable words (\%)

\begin{tabular}{c|c|c|c|c|c|c}
\hline \multirow{2}{*}{} & \multicolumn{3}{|c|}{ 3-syllables } & \multicolumn{3}{c}{ 4-syllables } \\
\cline { 2 - 7 } & RA & RS & SS & RA & RS & SS \\
\hline Pre & 0 & 73.3 & 55 & 0 & 65 & 42.5 \\
\hline Post & 10 & 80 & 72.5 & 30 & 75 & 58.8 \\
\hline
\end{tabular}

RA, response accuracy; RS, retrieval score; SS, sequencing score.

\subsection{3. 첨가오류 발생률 변화}

그림 2는 중재 단계 12 회기 동안의 첨가오류 발생률을 도식 화한 것이다. 1 회기에서는 $11.6 \%$ 의 첨가오류 발생률을 나타내 었고 4 회기 때 $14.3 \%$ 로 증가하였으나, 이후 회기부터 점차 감소 하여 중재 중반부인 6회기부터는 $10 \%$ 미만으로 측정되었으며, 마지막 12 회기에서는 $2.2 \%$ 의 첨가오류를 보였다. 즉, 중재 회기 가 진행됨에 따라 첨가오류의 발생률이 뚜렷이 감소하는 것을 확인할 수 있었다.

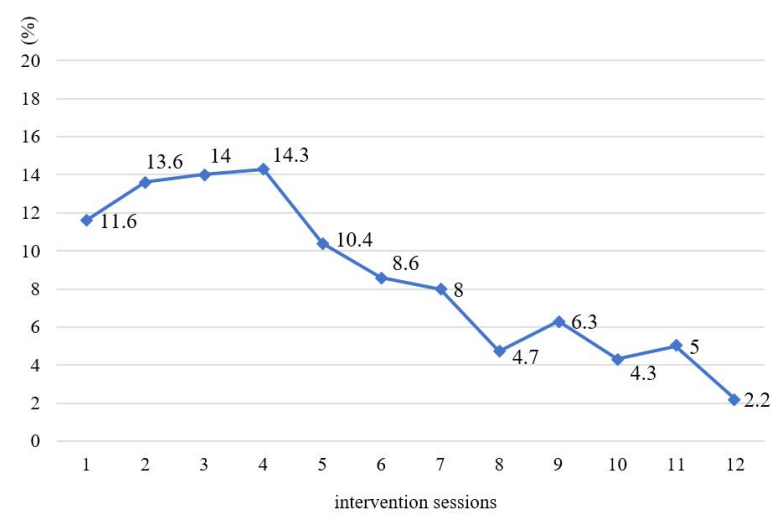

그림 2. 중재회기에서의 첨가오류 변화

Figure 2. The change of addition errors in intervention sessions 


\subsection{4. 자음정확도 및 모음정확도 변화}

중재 전 아동은 우리말 조음·음운평가(Kim \& Shin, 2004)에서 자음정확도 $32.5 \%$, 모음정확도 $50 \%$ 를 나타내어, 매우 낮은 음 소정확도를 보여주었다(표 2). 중재 후 자음정확도는 $55.8 \%$, 모 음정확도는 $70 \%$ 로 평가되어 여전히 심각한 말소리장애에 해당 하였지만, 중재 전과 비교하여 공식검사 상으로도 자음과 모음 정확도 모두 향상되었음을 확인할 수 있다.

\section{4. 논의 및 결론}

본 연구는 국외에서 개발된 비단어 중재를 수정 및 보완하여 한국어 비단어 중재접근법의 가이드라인을 정립하고, 이를 말 실행증 아동에게 직접 적용하여 그 효과를 확인하기 위해 수행 되었다. 보다 근본적으로는 비단어를 활용한 중재가 손상된 말 운동프로그래밍 단계를 개선하는데 효과적인지, 그 효과는 비 단어 뿐만 아니라 실제 단어로 일반화되는지 확인하여 아동기 말실행증의 새로운 중재접근법을 제안하는데 목적이 있다. 한 국어 비단어 중재접근법의 기반의 되는 ReST의 핵심은 중재에 사용되는 비단어를 '아동 맞춤형'으로 제작하는 과정에 있다. 그러나 ReST는 ‘영어권 아동 맞춤형'으로 자극어 선정 시 모음 의 장단과 강약을 구분하는 등 영어의 특성을 반영한 기준을 제 시하고 있다. 따라서 이 기준을 그대로 사용하기에는 무리가 있 다고 판단하여 ReST를 수정 및 보완한 새로운 비단어 중재접근 법을 제안하고자 하였다. 본 연구에서 제안하는 비단어 중재접 근법은 첫째, 자극어 선정 기준이 한국어에 적합하고, 둘째, 세 밀한 진전 평가를 위한 구체적인 채점 체계를 가졌으며, 셋째, 단어로의 일반화 효과를 확인하기 위한 선정 기준을 확립하여 비단어 중재의 궁극적인 목적을 간과하지 않는 것을 특징으로 한다. 이렇게 수정된 가이드라인은 한국어를 기반으로 체계적 인 절차를 가진 한국어 버전의 비단어 중재접근법을 제안하였 다는 점에서 의의가 있을 것으로 기대한다.

한국어 비단어 중재접근법을 이용하여 아동기 말실행증에게 적용한 결과는 다음과 같다. 첫째, 중재한 3 음절 비단어의 반응 정확도, 인출 점수, 배열 점수가 향상되었다. 둘째, 중재하지 않 은 3음절 비단어의 모든 지표가 향상되었으며, 특히 배열 점수 가 큰 폭으로 향상되었다. 이는 4음절 비단어에서도 비슷한 양 상으로 나타났다. 셋째, 중재하지 않은 3 음절, 4 음절 단어의 모 든 지표가 향상되었다. 향상의 정도는 비단어에 대한 일반화 효 과에 비해 작았다. 넷째, 중재 회기가 진행됨에 따라 3 음절 목표 비단어에 대한 첨가오류가 큰 폭으로 감소하였다. 다섯째, 중재 후 말소리장애 공식검사의 표준화 지표인 자음정확도 및 모음 정확도의 향상을 보였다. 이상의 결과 각각에 대해 다음과 같은 고찰을 하고자 한다.

먼저 중재가 이루어진 3 음절 비단어의 반응정확도, 인출 점 수, 배열 점수가 향상되었으며, 그 중에서도 반응정확도는 눈에 띄는 상승 곡선을 나타내었다. 이는 대상 아동의 두드러진 구어 특징이었던 산출의 비일관성이 크게 개선됨으로써 나타난 결 과로 보인다. 아동은 중재 초기 목표 비단어 /마게쭈/를 [마데
쭈], [마예추], [마께쭈] 등과 같이 비일관적으로 산출하였다. 그 러나 회기가 진행됨에 따라 아동의 비일관성은 크게 감소하여 사전 평가 시 $51.8 \%$ 로 측정된 변이율(percentage of inconsistency) 은 $30.7 \%$ 로 감소하였다. 아동은 비록 오류를 보일지라도 대부 분의 항목에서 일관된 오류를 나타내었으며, 일관성이 생긴 오 류는 반복적 훈련을 통해 정반응으로 이어졌다. 그렇지만 여기 서 간과하면 안 되는 점은 집중적으로 반복 연습한 비단어는 더 이상 비단어로서의 기능, 즉 새로운 운동프로그래밍을 유도하 는 도구 역할을 하지 못한다는 것이다. 다시 말해 일부 중재 비 단어의 산출과정은 충분히 학습된 근육명령의 조합과 성공적 인 반복 산출로 인해, 이제는 더 이상 즉각적 운동프로그래밍이 아닌, 잘 저장된 운동프로그램에 의해 정확하게 산출되었을 수 있다.

이러한 연구 결과와 가설은 아동기 말실행증의 근본적인 개 선책에 대해 시사하는 바가 크며, 이를 바탕으로 말실행증 아동 의 새 단어학습에 대한 다음과 같은 가이드라인을 제시할 수 있 다. 첫째, 아동기 말실행증의 경우 새로운 단어의 초기 학습 시 해당 단어를 정확하게 산출하는 방법을 구체적으로 알려주고, 그 단어를 반복하게 하며, 아동의 반응에 대해 명확한 피드백을 제공하는 것이 매우 중요하다. 여러 상황적 단서와 함께 새 단 어에 반복 노출되면 자연스럽게 그 단어를 습득하는 일반 아동 의 단어학습과정을 말실행증 아동에게 기대해서는 안 될 것이 다. 부모 혹은 주변 성인들의 완성된 말소리자극을 들음과 동시 에 그것을 즉각적으로 정확하게 따라 할 수 있는 우수한 말운동 프로그래밍을 가지고 있는 일반 아동과 달리, 말실행증 아동은 말운동프로그래밍 결함으로 인해 새 말소리자극을 정확하게 따라 할 수 있는 능력이 제한적이다. 새 단어를 처음 접할 때 모 호하게 연결된 운동프로그래밍은 이후 그 단어에 대한 부정확 하고 불명료한 운동프로그램으로 저장되어, 해당 단어를 산출 할 때마다 정확하지도, 일관적이지도 않은 발음을 하게 되는 것 이다. 둘째, 새로운 단어를 정확하게 발음하는 방법을 습득하면 그 직후에는 과할 정도로 여러 차례 해당 단어를 반복할 기회를 가져야 한다. 공들여서 연결한 말운동프로그래밍은 반복 산출 을 통해서만 견고한 말운동프로그램으로 저장될 수 있다. 이러 한 과정을 거친다면 말실행증 아동의 경우에도 해당 단어에 대 해서는 정확하고 일관적인 산출을 기대해 볼 수 있을 것이다.

앞에서 언급하였듯이 반복 연습된 비단어의 산출은 더 이상 말운동프로그래밍 단계를 반영하지 못한다. 따라서 본 중재가 실제로 대상 아동의 말운동프로그래밍 능력 개선에 효과적이 었는지 확인하기 위해, 중재하지 않은 비단어로의 일반화를 확 인하였다. 그 결과 중재하지 않은 3 음절 비단어의 반응정확도, 인출 점수 및 배열 점수가 모두 향상되었음을 확인하였는데, 가 장 주목할 점은 배열 점수의 변화였다. 3 음절 배열 점수의 경우 49.1점에서 90.8점으로 대폭 상승하였다(표 6). 일반화 평가에 사용된 비단어는 중재에 사용된 비단어와 음소 구성(/ㅁ/, /E/,/ 찌, / ᄀ/, / / /, /T/, / / /, / ㄱ//)이 동일하였지만 배열에는 분명한 차이가 있었다. 따라서 인출 점수의 향상은 충분히 예상 가능한 결과일 수 있으나, 배열 점수는 그렇지 않다. 음소 배열의 명확 
한 차이가 있음에도 향상된 배열 점수의 결과는 아동 반응에 대 한 질적 분석을 통해 설명이 가능하다. 비단어 중재 초기, 아동 은 음소 간 동시조음 전환의 연장을 지속적으로 나타내었으며, 이로 인해 본인의 평소 음운오류패턴 특성과 유사하게 마치 어 중종성이 첨가되는 듯한 인상을 일관되게 보였다(/기메타/-[김 메타]). 이와 관련하여 중재 단계의 첨가오류 양상을 분석해본 결과, 1 회기 $11.6 \%$ 에서 4 회기 $14.3 \%$ 로 증가하였으나 이후 회기 부터 점차 감소하여 6 회기에는 $10 \%$ 미만, 마지막 회기에서는 $2.2 \%$ 으로 첨가오류가 두드러지게 감소한 것을 확인할 수 있었 다(그림 2). 시작점과 끝점에서 순차적으로 음소 위치를 맞춰가 며 점수를 산출하는 배열 점수의 채점 방식을 고려할 때, 첨가 오류는 두 시작점 모두에서 음소의 배열을 붕괴시켜, 동일한 반 응(예: /투짜메/-[투짬메])에 대해 인출 점수(예: 6점/6점)보다 배 열 점수(예: 7점/12점)에 더 큰 영향을 미친다. 따라서 중재하지 않은 비단어의 배열 점수가 큰 폭으로 향상된 것은 중재 단계에 서 보인 첨가오류의 감소로 인해 초래된 결과라 할 수 있다. 첨 가오류가 말실행증의 운동계획/프로그래밍의 결손을 신뢰성 있게 반영한다는 선행연구(Shriberg et al., 2012)에 근거하였을 때, 대상 아동이 보인 첨가오류의 감소는 말운동프로그래밍의 개선을 나타내는 지표라 할 수 있다.

이러한 양상은 4음절 비단어에서도 유사하게 나타났다. 운동 생리적인 측면에서 1 음절의 증가는, 더군다나 아동기 말실행증 에게 있어 매우 부담스러운 변화이다. 음절수가 증가함에 따라 근육명령의 요구 또한 증가하게 되고 이는 말운동프로그래밍 단계에 결함이 있는 아동기 말실행증에게 결코 쉽지 않은 과제 이기 때문이다. 사전-사후 평가 시 반응정확도가 모두 0점이었 다는 것은 본 아동에게도 4음절 비단어를 산출하는 것이 얼마 나 도전적인 과제였는지를 짐작하게 한다. 그러나 인출 및 배열 점수의 경우 4 음절 비단어에서도 각각 $15 \%, 25 \%$ 씩 향상되었다 (표 6). 이러한 결과는 대상자가 아직은 4음절 비단어를 완전하 게 정조음하지 못하지만, 정조음에 근접해가고 있음을 보여주 며, 인출 및 배열 점수는 그 정도를 측정할 수 있는 유용한 지표 임을 시사한다.

또한 본 연구에서는 비단어가 단어를 말하기 위한 템플릿의 역할을 할 수 있는지 확인하고자 하였으며, 이에 3음절, 4음절 단어로의 일반화 평가를 실시하였다. 그 결과 3음절, 4음절 단 어의 반응정확도는 $0 \%$ 에서 각각 $10 \%$ 와 $30 \%$ 로 상승하여, 비단 어 중재를 통해 단어로의 일반화를 기대할 수 있음을 확인하였 다. 일반화 단어는 중재 비단어와 유사한 음소들로 구성되었고, 때문에 일반화 평가에 사용된 단어는 아동이 중재 시 이미 여러 차례 성공적으로 산출한 적 있는 운동연쇄들의 조각으로 구성 되어 있음을 고려할 때, 단어로의 일반화 효과는 충분히 타당한 결과로 보인다. 이때 한 가지 의아한 점은 3 음절보다 4 음절 단 어에서 더 큰 상승효과가 있었다는 것인데, 이러한 결과는 4음 절 일반화 평가 단어목록을 통해 설명 가능하다. 연구방법에서 기술하였듯이 일반화 평가에 사용된 단어 선정 기준은 첫째, 목 표 비단어와 동일하거나 유사한 자음들로 구성되었을 것, 둘째, 종성을 포함하지 않는 구조일 것의 두 가지였다. 그러나 4음절
단어의 경우 모든 음절에 종성이 존재하지 않는 단어는 매우 제 한적이었기에, 4음절 단어 10 개 중 5 개는 ‘토끼', ‘모자'를 조합 하여 '토끼모자'를 만든 것처럼 2음절 단어 두 개를 조합하여 제 작하였다. 이와 같은 4음절 단어 제작방법이 아동에게는 이점 으로 작용하여, 3 음절에 비해 4음절 단어에서 더 큰 향상을 보 인 것으로 사료된다. 실제로 아동이 정반응한 4음절 단어는 모 두 2음절 조합으로 이루어진 항목들이었다. 이러한 결과 또한 긴 단어일지라도 그 단어를 구성하는 운동연쇄의 부분들이 아 동에게 익숙한 것일 경우 충분히 정조음을 기대할 수 있다는 것 을 시사한다.

뿐만 아니라 단어로의 일반화에서도 배열 점수의 향상이 눈 에 띄었다. 그러나 향상 정도는 비단어의 경우보다 미미하였는 데, 이는 6주의 중재가 강력하게 습관화된 오류를 개선시키기 에는 짧은 시간일 수 있음을 상기시킨다. 빈번하게 사용하는 단 어는 그것이 오류일지라도, 이미 학습화된 근육명령의 조합에 의해 자동적으로 수행되기 때문에, 습관화된 오류를 고치는 것 은 쉽지 않은 일일 것이다. 그럼에도 불구하고 3,4 음절 단어의 모든 지표에서 상승세를 보인 것은 의미 있는 결과이다. 대상 아동은 사전 평가에서/주사기/를 [주깍키], /거부기/를 [겁끄디], /고구마/를 [고몸마]로 발화하였고, 이때 보인 첨가오류와 경음 화오류는 비정상적인 예기적 동시조음에서 발현된 전환오류임 을 알 수 있다. 그러나 저장된 어휘집의 영향, 즉 하향식 처리의 범위를 벗어난 비단어 중재를 이용하여 하나의 조음제스처에 서 다음 제스처로 정확한 타이밍에 전환하는 훈련을 반복 실시 하였고, 이를 통해 보다 민첩한 음소 간 전환을 수행할 수 있게 되었다. 이러한 전환 능력의 개선은 단어로 일반화되어 사후 평 가에서 측정된 첨가오류 비율은 $0 \%$ 로 관찰되었으며, 이는 배열 점수의 향상으로 연결되었다. 이와 같은 결과들을 종합해볼 때, 비단어 중재는 고착화된 단어 오류의 개선에 긍정적인 영향을 미칠 수 있는 효과적인 방법으로 보인다. 다만, 본 연구에서 실 시한 주 2 회보다 더욱 집중적이고 반복적인 치료 회기가 설계 된다면, 더 큰 효과를 기대해 볼 수 있으리라 여겨진다.

본 연구 결과는 국내 비단어 연구의 스펙트럼을 넓히는 계기 가 되는 것은 물론, 여전히 큰 고민을 안겨주고 있는 아동기 말 실행증의 중재 방법에 대한 실마리가 될 수 있을 것으로 기대한 다. 그러나 이상과 같은 본 연구의 의의에도 불구하고, 본 연구 는 다음과 같은 제한점을 갖는다. 무엇보다 단일 대상자를 중심 으로 수행된 단일대상연구라는 점에서 그 제한점을 부정할 수 없다. 개별 대상자를 중심으로 중재의 효과를 심도 있게 평가할 수 있도록 계획된 연구 방법이기는 하지만, 통계적으로 유의미 한 차이를 검증할 수 없다는 방법적 한계를 가진다. 따라서 본 연구 결과를 일반화하는 데에는 주의를 기울여야 할 것이다. 또 다른 제한점은 운율 능력의 변화에 대한 객관적 수치를 제시하 지 못했다는 점이다. 본 연구가 참고한 ReST는 음소 정확성, 전 환 능력, 운율의 향상을 목표로 하는 중재법이다. 그럼에도 불 구하고 $\operatorname{ReST}$ 또한 운율의 측정을 모델링해준 운율과 동일한지 에 대해 검사자의 단순한 청지각적 판단에 의존하고 있다. 운율 능력을 보다 객관적으로 평가할 수 있는 도구 또는 방법의 부재 
로 인해, 본 연구에서도 검사자의 청지각적 판단으로만 운율 능 력을 평가하였다. 본 아동의 경우 말실행증 진단 체크리스트의 네 번째 항목인 운율 결함은 관찰되지 않았으나, 이를 보다 객 관적이고 심층적으로 평가할 경우 미세한 결함을 보일 가능성, 그로 인해 운율적 측면에서 중재 효과가 달라질 가능성 등을 배 제할 수 없을 것이다. 마지막으로 본 중재 방법은 말실행증의 핵심적 특징이자 본 아동의 두드러진 특징이었던 비일관성을 직접적으로 다루어주고 있지는 않다는 점을 염두에 두어야 할 것이다. 말운동프로그래밍 능력의 향상 및 반복 훈련을 통한 말 운동프로그램의 견고한 저장을 유도하고 있지만, 그것이 실제 말산출 시 비일관성 감소로 연결되는지에 대해서는 추후 연구 에서 다뤄보아야 할 것이다. 따라서 이후 진행되는 연구에서는 적절한 규모의 대상자를 모집하여 대상자간 중다기초선설계 (multiple baseline across subject) 혹은 집단연구를 통해 내적타당 도를 강화하고, 운율평가에 대한 지표를 마련하여 중재로 인한 비일관성 감소 효과를 확인하는 것과 같이 방법적 측면을 보강 한 중재연구로 발전할 필요가 있다.

\section{References}

American Speech-Language-Hearing Association. (2007). Childhood apraxia of speech. Rockville, MD: ASHA.

Ballard, K. J., Robin, D. A., McCabe, P., \& McDonald, J. (2010). A treatment for dysprosody in childhood apraxia of speech. Journal of Speech, Language, and Hearing Research, 53(5), 1227-1245.

Bernthal, J. E., Bankson, N. W., \& Flipsen, P., Jr. (2013). Articulation and phonological disorders: Speech sound disorders in children (7th ed.). Upper Saddle River, NJ: Pearson.

Forrest, K. (2003). Diagnostic criteria of developmental apraxia of speech used by clinical speech-language pathologists. American Journal of Speech-Language Pathology, 12(3), 376-380.

Grigos, M. I., Moss, A., \& Lu, Y. (2015). Oral articulatory control in childhood apraxia of speech. Journal of Speech, Language, and Hearing Research, 58(4), 1103-1118.

Kim, H. J., Choi, S. Y., \& Ha, J. W. (2015). Speech-motor program/programming in children with childhood apraxia of speech, children with articulatory and phonological disorders and typically developing children. Communication Sciences \& Disorders, 20(1), 60-71.

Kim, N. Y., \& Ha, J. W. (2014). Phonological representations in children with articulation and phonological disorders. Communication Sciences \& Disorders, 19(2), 226-237.

Kim, Y. T., \& Shin, M. J. (2004). Urimal test of articulation and phonology (U-TAP). Seoul, Korea: Hakjisa.

Kim, Y. T., Hong, G. H., Kim, K. H., Jang, H. S., \& Lee, J. Y. (2009). Receptive \& expressive vocabulary test (REVT). Seoul, Korea: Seoul Community Rehabilitation Center.

Kim, Y. T., Seong, T. J., \& Lee, Y. K. (2003). Preschool receptive- expressive language scale (PRES). Seoul, Korea: Seoul Community Rehabilitation Center.

Kwon, Y. H. (2008). Changes in cortical and neuromuscular modification induced by visuo-motor skill learning in young healthy subject (Doctoral dissertation). Daegu University, Daegu, Korea.

Lee, H. R., \& Sim, H. S. (2004). Literature review on differential diagnosis of apraxia of speech (AOS). Special Education Research, 3(1), 147-165.

Lim, H. C. (2004). Korean Raven's coloured progressive matrix (K-CPM). Seoul, Korea: Hankuk Guidance.

Maas, E., Gildersleeve-Neumann, C. E., Jakielski, K. J., \& Stoeckel, R. (2014). Motor-based intervention protocols in treatment of childhood apraxia of speech (CAS). Current Developmental Disorders Reports, 1(3), 197-206.

McCabe, P., Murray, E., Thomas, D. C., \& Evans, P. (2017). Clinician manual for rapid syllable transition treatment (REST). Camperdown, Australia: The University of Sydney.

Murray, E., McCabe, P., \& Ballard, K. J. (2012). A comparison of two treatments for childhood apraxia of speech: Methods and treatment protocol for a parallel group randomised control trial. BMC Pediatrics, 12(1), 1-9.

Murray, E., McCabe, P., \& Ballard, K. J. (2014). A systematic review of treatment outcomes for children with childhood apraxia of speech. American Journal of Speech-Language Pathology, 23(3), 486-504.

Murray, E., McCabe, P., \& Ballard, K. J. (2015). A randomized controlled trial for children with childhood apraxia of speech comparing rapid syllable transition treatment and the nuffield dyspraxia programme - third edition. Journal of Speech, Language, and Hearing Research, 58(3), 669-686.

Nijland, L., Maassen, B., \& van der Meulen, S. (2003). Evidence of motor programming deficits in children diagnosed with DAS. Journal of Speech, Language, and Hearing Research, 46(2), 437450.

Park, H. (2008). A study of naming abilities in children with developmental apraxia of speech. Journal of Speech \& Hearing Disorders, 17(2), 35-49.

Park, M. S. (2015). Characteristics of coarticulation in childhood apraxia of speech (Master's thesis). Yonsei University, Seoul, Korea.

Preston, J. L., Brick, N., \& Landi, N. (2013). Ultrasound biofeedback treatment for persisting childhood apraxia of speech. American Journal of Speech-Language Pathology, 22(4), 627-643.

Ryu, E. J., \& Ha, J. W. (2018). Development and application of nonsense syllable repetition test for evaluating phonological retrieval and sequencing abilities. Communication Sciences \& Disorders, 23(4), 992-1004. 
Schmidt, R. A., \& Lee, T. D. (1999). Motor control and learning: A behavioral emphasis (3rd ed.). Champaign, IL: Human Kinetics.

Shriberg, L. D., Lohmeier, H. L., Strand, E. A., \& Jakielski, K. J. (2012). Encoding, memory, and transcoding deficits in childhood apraxia of speech. Clinical Linguistics \& Phonetics, 26(5), 445482.

Song, Y. K. (2008). Comparison of compensation ability of speech motor control and ability of speech motor programming in children with and without articulation disorders (Doctoral dissertation). Ewha Womans University, Seoul, Korea.

Stackhouse, J., \& Wells, B. (1993). Psycholinguistic assessment of developmental speech disorders. International Journal of Language \& Communication Disorders, 28(4), 331-348.

Swinnen, S. P., Schmidt, R. A., Nicholson, D. E., \& Shapiro, D. C. (1990). Information feedback for skill acquisition: Instantaneous knowledge of results degrades learning. Journal of Experimental Psychology: Learning, Memory, and Cognition, 16(4), 706-716.

Thomas, D. C., McCabe, P., \& Ballard, K. J. (2017). Combined clinician-parent delivery of rapid syllable transition (ReST) treatment for childhood apraxia of speech. International Journal of Speech-Language Pathology, 20(7), 683-698.

Thomas, D. C., McCabe, P., Ballard, K. J., \& Bricker-Katz, G. (2017). Parent experiences of variations in service delivery of rapid syllable transition (ReST) treatment for childhood apraxia of speech. Developmental Neurorehabilitation, 21(6), 391-401.

van der Merwe, A., \& Steyn, M. (2018). Model-driven treatment of childhood apraxia of speech: Positive effects of the speech motor learning approach. American Journal of Speech-Language Pathology, 27(1), 37-51.

Vance, M., Stackhouse, J., \& Wells, B. (2005). Speech-production skills in children aged 3-7 years. International Journal of Language \& Communication Disorders, 40(1), 29-48.

Winstein, C. J., \& Schmidt, R. A. (1990). Reduced frequency of knowledge of results enhances motor skill learning. Journal of Experimental Psychology: Learning, Memory, and Cognition, 16(4), 677-691.

\section{- 오다희 (Da-Hee Oh)}

대구대학교 재활과학과 언어치료전공 박사과정 고려대학교 의과대학 융합뇌신경연구소 연구원 경상북도 경산시 진량읍 대구대로 201

Tel: 053-850-4327

Email: duhee03@gmail.com 관심분야: 말소리장애, 음운처리, 말운동장애

- 하지완 (Ji-Wan Ha) 교신저자

대구대학교 언어치료학과 교수
경상북도 경산시 진량읍 대구대로 201

Tel: 053-850-4327

Email: jw-ha@daegu.ac.kr

관심분야: 말소리장애, 음운처리, 말운동장애 
부록 1. 비단어 중재 회기 흐름도 (McCabe et al., 2017)

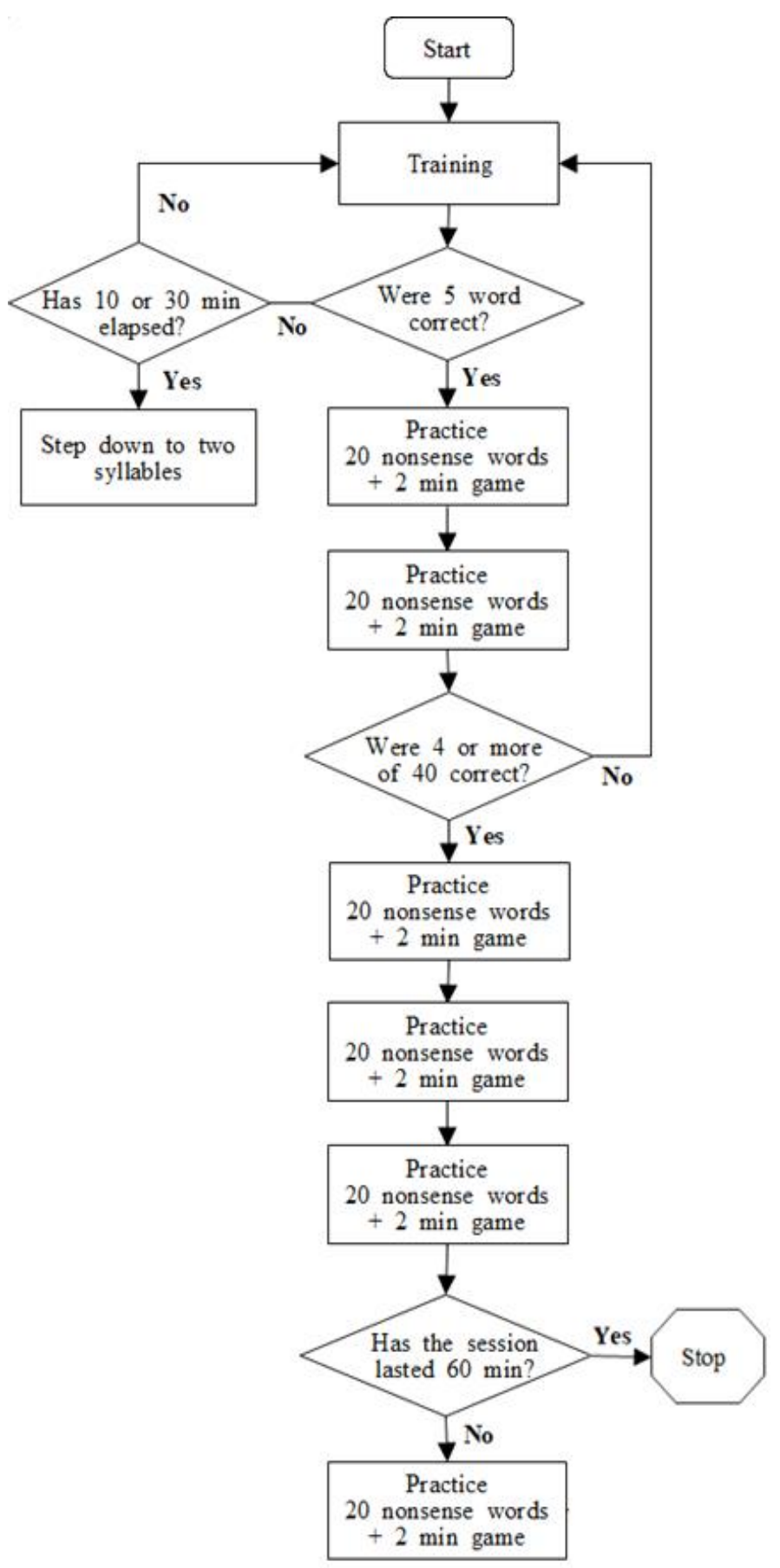




\title{
말운동프로그램 향상을 위한 한국어 비단어 중재접근법의 확립 및 임상 적용*
}

\author{
오 다 희 ${ }^{1,2} \cdot$ 하 지 완 ${ }^{3}$
}

${ }^{1}$ 대구대학교 대학원 재활과학과, ${ }^{2}$ 고려대학교 의과대학 융합뇌신경연구소, ${ }^{3}$ 대구대학교 언어치료학과

\begin{abstract}
국문초록
본 연구는 국외에서 개발된 비단어 중재접근법을 수정 및 보완하여 한국어 비단어 중재접근법을 확립하고, 아동기 말실행증 아동에게 직접 적용하여 그 효과를 확인하기 위해 실시되었다. 궁극적인 목적은 비단어를 이용한 중재가 아동기 말실행증의 말운동프로그래밍 능력을 개선시켜 비단어 산출 및 단어로의 일반화에 효과적인지 알아보기 위함에 있다. 중재는 아동기 말실행증의 진단 특성을 보이는 5 세 6 개월의 남아를 대상으로, $\mathrm{ABA}$ 설계를 사용한 단 일대상연구를 실시하였다. 중재에 사용된 비단어는 아동 맞춤형으로 제작하였으며, 한 회기당 60 분씩 주 2 회로, 총 12 회기를 실시하였다. 그 결과 중재한 3 음절 비단어의 모든 지표가 향상되었으며, 중재하지 않은 3 음절, 4 음절 비 단어 및 단어로의 일반화를 확인하였다. 단, 단어로의 일반화 효과는 비단어로의 일반화 효과에 비해 미비하였다. 비단어 중재는 대상 아동의 말운동프로그래밍 능력을 개선시키는데 효과적이었다. 그 결과 운동프로그래밍 손상 에 기인한 전환 오류가 크게 감소하였고, 중재하지 않은 비단어의 산출 능력이 큰 폭으로 증가하였다. 그러나 강력 하게 습관화된 단어 오류를 완전히 개선시키는 데에는 한계가 있었으며, 이는 보다 집중적이고 반복적인 중재 일 정을 제공했을 때 기대할 수 있는 결과일 것이다.
\end{abstract}

핵심어: 아동기 말실행증, 비단어 중재접근법, 말운동프로그래밍

\section{참고문헌}

권용현(2008). 운동학습이 대뇌피질의 흥분성과 신경 전달 속도 및 근육 적응성에 미치는 영향 대구대학교 박사학위논문.

김나연, 하지완(2014). 조음음운장애아동과 일반 아동의 음운표 상의 질과 음운표상 부호화 능력 비교. 언어청각장애연구, 19(2), 226-237.

김영태, 신문자(2004). 우리말 조음·음운평개(U-TAP). 서울: 학 지사.

김영태, 성태제, 이윤경(2003). 취학전 아동의 수용언어 및 표현 언어 발달 척도(PRES). 서울: 서울 장애인 종합복지관.

김영태, 홍경훈, 김경희, 장혜성, 이주연(2009). 수용·표현어휘 력검사 $(R E V T)$. 서울: 서울 장애인 종합복지관.

김효정, 최선영, 하지완(2015). 아동기 말실행증, 조음음운장애 및 일반 아동의 말-운동프로그램/프로그래밍 능력 비교. 언어 청각장애연구, 20(1), 60-71.

류은주·하지완(2018). 음운 인출 및 배열 처리능력 평가를 위한 무의미 음절 따라말하기 검사의 개발 및 적용. 언어청각장애 연구, 23(4), 992-1004.
박민수(2015). 아동기 말실행증 아동의 동시조음 특성. 연세대학 교 석사학위논문.

박희정(2008). 발달성 말실행증 아동의 이름대기 능력에 대한 연 구. 언어치료연구, 17(2), 35-49.

송윤경(2008). 조음장애아동과 비장애아동의 말운동통제 보상 능력 및 말운동프로그래밍 능력 비교. 이화여자대학교 박사 학위논문.

이희란·심현섭(2004). 말실행증(AOS)의 변별진단(differential diagnosis)에 관한 문헌고찰. 특수교육, 3(1), 147-165.

유승미(2016). 한국어 낭독과 자유 발화의 운율 특성 연구. 연세 대학교 박사학위논문.

임호찬(2004). 한국판 레이븐 지능검새(K-CPM). 서울: 한국가이 던스.

\footnotetext{
* 이 논문은 2020년도 정부(교육부)의 재원으로 한국연구재단의 지원을 받아 수행된 기초연구사업임(NRF-2020R1I1A3074130).
} 